Commentary

\title{
Alternative and Resistance Movements: The Two Faces of Sustainability Transformations? ${ }^{\text {ir }}$
}

\author{
Jérôme Pelenc $^{\mathrm{a}, *}$, Grégoire Wallenborn ${ }^{\mathrm{a}}$, Julien Milanesi ${ }^{\mathrm{b}}$, Léa Sébastien ${ }^{\mathrm{c}}$, Julien Vastenaekels ${ }^{\mathrm{a}}$, \\ Fany Lajarthe $^{\mathrm{d}}$, Jérôme Ballet ${ }^{\mathrm{e}}$, Manuel Cervera-Marzal ${ }^{\mathrm{f}}$, Aurélie Carimentrand ${ }^{\mathrm{g}, \mathrm{h}}$, \\ Nicolas Merveille ${ }^{i, j}$, Bruno Frère ${ }^{k}$ \\ ${ }^{a}$ Université Libre de Bruxelles, IGEAT-CEDD, Av. F. D. Roosevelt, 50, B-1050 Brussels, Belgium \\ ${ }^{\mathrm{b}}$ CERTOP, UMR 5044 (CNRS, UTM, UPS), 31077 Toulouse cedex 4, France \\ ${ }^{\mathrm{c}}$ GEODE, UMR 5602 (CNRS, UT2J), Maison de la Recherche de l'Université Jean Jaurès, 5 Allées A. Machado, 31058 Toulouse Cedex 1, France \\ ${ }^{\mathrm{d}}$ Fonds de la Recherche Scientifique (F.R.S.-F.N.R.S.), Université Libre de Bruxelles, IGEAT-CEDD, Av. F. D. Roosevelt, 50, B-1050 Brussels, Belgium \\ ${ }^{\mathrm{e}}$ Université de Bordeaux-GREThA, Avenue Léon Duguit, 33608 Pessac, France \\ ${ }_{\mathrm{f}}^{\mathrm{f}}$ DICE (UMR 7318), Aix-Marseille Université, Faculté de droit - Espace René Cassin, 3 avenue Robert Schuman, 13628 Aix-en-Provence Cedex 1, France \\ ${ }^{\mathrm{g}}$ CIRAD, UMR INNOVATION, F-34398 Montpellier, France \\ ${ }^{\mathrm{h}}$ INNOVATION, Univ Montpellier, CIRAD, INRA, Montpellier SupAgro, Montpellier, France \\ ${ }^{\mathrm{i}}$ Département de stratégie, responsabilité sociale et environnementale, École des sciences de la gestion, Université du Québec à Montréal, Case postale 8888, succursale \\ Centre-ville, Montréal, Québec H3C 3P8, Canada \\ ${ }^{\mathrm{j}}$ Chaire Internationale sur le Cycle de Vie, École Polytechnique Montréal et École des sciences de la gestion, C.P. 6079, succ. Centre-Ville, Montréal, Québec H3C 3A7, \\ Canada \\ ${ }^{\mathrm{k}}$ Fonds de la Recherche Scientifique (F.R.S.-F.N.R.S.), University of Liège, Quartier Agora Place des orateurs, 3 (B.31), 4000 Liège, Belgium
}

\section{Introduction}

Contemporary global socio-environmental changes - both in the Global North and South - are characterized by an increasing number of people adopting alternative economic practices and lifestyles, such as Transition towns, Degrowth, the Commons movement, Buen vivir and Rights of Nature (Escobar, 2015), and by an increasing number of environmental resistance movements (see the global environmental justice movement, for example, Martinez-Alier et al., 2016). As explained by Avelino et al. (2016), sustainability transformations involve profound social changes and inevitably raise political questions regarding the current, unsustainable socio-ecological order. However, authors from Political Ecology (Swyngedouw and Kaika, 2014; Kenis and Lievens, 2014, among others) argue that neoliberal environmental governance, as a manifestation of the post-political order, has tended to reduce sustainability issues to technical questions through the imposition of a techno-scientific and economic rationality, and through statecontrolled procedures of so-called "participation". Thus, eco-modernization and green economy discourses dominate. From this perspective, "Questions of socio-ecological inequality, environmental destruction and its associated power relations are relegated to an issue of effective techno-scientific eco-management (Swyngedouw and Kaika, 2014, p468).
We argue that a social movement perspective would be interesting to challenge the issue of sustainability depoliticization.

Indeed, social movements, by definition, challenge power structures and seek social transformations (Della Porta and Diani, 2006). However, according to Temper et al. (2018, p2): “apart from some limited work (e.g. Geels, 2006; Scoones et al., 2015), to date sustainability science literature has not paid sufficient attention to the role that social movement activity and resistance play in transformations". Strengthening the development of a social movement approach to sustainability issues in Ecological Economics (EE) would appear to bring potential benefits to the field. Indeed, scholars from EE and sustainability science in general have long argued for the development of transdisciplinarity approaches (Jahn et al., 2012) and post-normal science (Funtowicz and Ravetz, 1994; Castro e Silva and Teixeira, 2011). Moreover, it would also be a means for advancing the possibility of (re)politicizing sustainability issues. Therefore, a rapprochement between sustainability scholars and social movements seems a relevant path to follow if we want the field to be really transdisciplinary and capable of advancing the co-production of knowledge between scholars and activists (Temper et al., 2018). If we refer to the very basic definition of EE formulated by Costanza (1991) i.e. "the science and management of sustainability", we understand that EE does not only have a cognitive goal (the production of

\footnotetext{
4 This article is submitted to the 'commentary' rubric of Ecological Economics. As explained by Funtowicz and Ravetz (1994, p.197): “[...] In that way, essays that

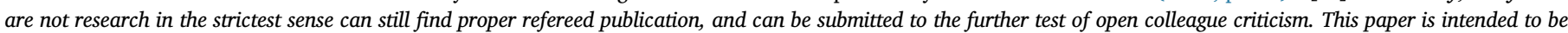

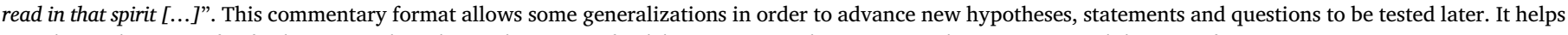
to indicate directions for further research and stimulate scientific debate on particular issues (in this case sustainability transformations).

* Corresponding author.

E-mail address: jerome.pelenc@gmail.com (J. Pelenc).
} 
knowledge about socio-ecological systems), but also an action goal i.e. to help the transformations of socio-ecological systems toward more sustainable paths (Baumgärtner et al., 2008). From this perspective, EE scholars could possibly embrace an "activist-research" position that can be defined as "scholarly engagement with activism and socio-ecological movements where researchers become scholar-practitioners practicing an applied, practical political ecology" (Demmer and Hummel, 2017, p611). Therefore, the aim of this commentary is to contribute to the debate about sustainability transformation processes in the field of EE through the lens of social movements.

Numerous definitions of 'social movement' exist, but here we have adopted a definition inspired by Della Porta and Diani (2006): a social movement is a process in which different actors engage in collective action. The authors identify the following principal characteristics that define a social movement: 1 ) social movement actors engage in political conflicts in order to achieve social change; 2 ) they engage in sustained exchange of resources in pursuit of common goals, thus building a dense network of informal ties; and 3) a social movement takes shape when collective identities develop beyond specific events and initiatives. The people engaged in them feel linked by ties of solidarity, and to some extent, with protagonists of other analogous movements.

In order to illustrate our argument we focus on some of the social movements that seem to drive transformations from the ground up toward sustainability and with which the authors are familiar. These movements are (i) from the resistance side: the global environmental justice movement, the resistance movement against useless and imposed mega-projects among others; (ii) and from the alternative side: degrowth, cooperatives movement, alternatiba, transition towns, community supported agriculture, social and solidarity economy and the "commons" movement. If we stick to the definition of social movement as presented above, we have to group movements into two categories. Indeed, they emerge from a different starting point: an openly declared conflict for environmental resistance movements and the creation of new more sustainable practices of consumption or production without openly declared conflict for alternative movements. The goal is not to set these two kinds of movements apart, but to identify the similarities and then ask if these different starting points (openly declared conflict or construction of alternatives) involve any form of continuity (or not) between the two types of movement in terms of sustainability transformations.

In line with Temper et al. (2018) who base their arguments on the work of Stirling (2015) and Pelling (2011) we differentiate between 'transition' and 'transformation'. Transition corresponds to processes of change managed under controlled conditions, within existing structures, through disciplined knowledge, and emphasizes technological innovation. The change is geared toward a known, presumably shared, achievable and measurable end. On the contrary, transformation refers to the reconfiguration of development patterns through changing the overarching global political economy which is dominated by neoliberal capitalism with increasing authoritarian tendencies. Transformation includes diverse, emergent and disruptive political processes that radically challenge existing structures. These processes of change are tied to social innovation (rather than technological innovation) and incommensurable knowledge in the pursuit of uncertain and contingent ends. To our understanding, social transformations should contribute to individual and collective emancipation and autonomy in the sense of Castoriadis $(1975,1986)$. Therefore, in this article we speak of transformation rather than transition because we aim to contribute to the development of a more political and emancipatory conception of sustainability.

The paper is structured as follows: Section 2 presents what we call the "alternative movements" (transition, degrowth, etc.) and Section 3 presents the "resistance movements" (environmental justice, placebased struggles, etc.). Section 4 presents the similarities of the two movements. The fifth section discusses the differences and continuities between these two movements and highlights some avenues of research. We conclude by advocating for a more social-movement oriented, politicized (or conflictualized) and spatialized (place-based) approach to sustainability transformation processes in Ecological Economics.

\section{The Rise of Socio-environmental Alternatives: Transition, Degrowth and the Humanization of the Economy}

Escobar (2015) put movements such as Degrowth, Transition town and Commons together under the banner of "transition discourses." This author sees these movements as contestations of the growth and development discourses emerging in the Global North and which share similarities with movements present in the Global South, such as Buen vivir and Rights of Nature. ${ }^{2}$

Researchers closer to the sociology of social movements see consumption alternatives and the solidarity economy as a way to resist neoliberal ideology (Laville, 2010; Hart et al., 2010; Pleyers, 2011) or as forms of everyday politicization and resistance (Frère, 2010; Frère and Jacquemain, 2013). In the same vein, other scholars speak of new social economic movements for those movements that use the "economy" rather than the conventional terrain of "politics" (political parties, trade unions, etc.) to challenge the dominant socio-political order (Gendron, 2001; Gendron and Turcotte, 2006). The new rise of the cooperative movement is an example of the latter (e.g. food cooperatives, energy cooperatives).

Finally, Kemp et al. (2016) explain that the many local alternatives that have sprung up throughout the world should not be considered as isolated but rather as the manifestation of what they call, in reference to Polanyi, a bottom-up movement for the "humanization of the economy." They use the term "humanization of the economy" as an umbrella term to cover activities of living and working based on values of reciprocity, responsibility, citizenship, integrity and autonomy, connectedness and trust (e.g. cooperatives, community supported agriculture and co-housing). These activities cover all sectors of the economy (e.g. food, energy, mobility and housing). From this perspective, creating local alternative lifestyles and communities can be seen as a means to put in practice a more socially and ecologically just society.

\section{The Environmental Resistance Movements}

According to Temper et al. (2018, p2): “While sustainability science literature is slowly engaging with the transformative power of resistance, supporters of environmental justice (EJ) movements and activists have been making this argument for long [...]". Indeed, Environmental resistance movements offer spaces in which empowerment and politicization are possible (Robert, 2014; Temper et al., 2015; Sebastien, 2017; MartinezAlier et al., 2016). Moreover, local environmental resistance confronts the commodification of nature and thus there are places where the dominant socio-ecological order can be directly contested (MartinezAlier et al., 2016). Furthermore, especially when associated with land occupation, resistance offers a space for experimenting with alternative ways of living (Kempf, 2014; Robert, 2014; Grisoni, 2015; Barbe, 2016). Martinez-Alier et al. (2016, p747), drawing on the worldwide atlas of environmental conflicts (ejatlas), highlight the global character of the environmental justice movement: "although almost all conflicts in

\footnotetext{
${ }^{1}$ We have assumed that these movements are fairly well known in the Ecological Economics community. For a detailed description of the Degrowth movement, see Demaria et al., 2013; for the transition movement, see Hopkins (2008 and 2013); for the Commons movement, see Bollier (2014). See also Beling et al. (2017) for a discussion on human development, degrowth and buen vivir in this journal.

${ }^{2}$ See Acosta and Martinez (2009a, 2009b) for detailed presentations of Buen Vivir and Rights of Nature.
} 
the EJ atlas are local and they target specific local grievances (...) the movement is global because such local events belong to classes of conflicts that appear regularly elsewhere in the world or because they raise the conflict issue to the global level (...) the actors involved in the conflicts are similar to some extend (...). We claim that there is a Global Environmental Justice Movement that shares some common goals, frames and forms of mobilization, although obviously there is no single united organization in charge, no politbureau or central committee". The global character of these local struggles can also be demonstrated by the nature of the claims that incorporate global issues such as climate change, etc., and are often linked with regional, national or international alter-globalization networks (Sikor and Newell, 2014; Armiero and D'Alisa, 2012).

Place-based struggles and local resistance represent common values and interests which often go beyond environmentalism alone (Anguelovski and Martinez-Alier, 2014). According to Armiero and D'Alisa (2012, p49), local resistance movements exemplify the failure of the de-politicization of the environment and offer an example of repoliticization at the local scale: "Instead, everything science, technology, the market, spaces, and bodies has become political....This, in turn, creates room for conflict and democratic participation."

In addition to re-politicization, these conflicts have societal impacts such as strengthening communities, developing knowledge/counterexpertise, and fostering place attachment (Armiero and D'Alisa, 2012; Anguelovski and Martinez-Alier, 2014; Martinez-Alier et al., 2016; Sebastien, 2017). Thus, local resistance offers, in a direct relation with environmental issues, concrete spaces where power, empowerment and politicization can be re-asserted. In sum, the political nature and transformative effects of local environmental resistance movements are increasingly recognized (Temper et al., 2015; Grisoni, 2015; Sebastien, 2017; Barbe, 2016; Martinez-Alier et al., 2016).

\section{Similarities Between Resistance and Alternative Movements}

In this section we highlight the similarities between resistance and alternative movements over three aspects (i) the creation of networks of actors across scales characterized by horizontal organization; (ii) the emergence of new collective and individual political identities; and (iii) the importance of the "place-based" character of both alternative and resistance movements.

Both resistance and alternative movements entail the creation of dense networks of formal and informal ties and resource exchange at local, national and even transnational levels. For example, the "transition network" is organised at local (transition towns), national (national hub) and international (international Transition Hub) levels. ${ }^{3}$ For the solidarity economy movement, in France for example, networks exist at the local (Pole territoriaux de cooperation économique), regional (Réseau des territoires pour une économie sociale et solidaire) and national level. Transnational networks also exist, such as the Intercontinental Network for the Promotion of the Social Solidarity Economy (RIPESS). The Degrowth movement brings academics and activists together annually or biannually at a conference; a summer school is organized every year, and national networks exist in France, Belgium, Spain, Italy, etc. The international Research and Degrowth platform makes the community visible worldwide.

Regarding environmental resistance, for example, the Environmental Justice Atlas (EJATLAS ${ }^{4}$ ) functions as an international platform, giving the movement some visibility on a global scale (see for more details Martinez-Alier et al., 2016). At the European level, the social movement against "unnecessary and imposed mega projects" brings together actors engaged in place-based struggles across western

\footnotetext{
${ }^{3}$ See the transition network map: https://transitionnetwork.org/transitionnear-me/).

${ }^{4}$ http://ejatlas.org/.

5 https://www.forum-gpii.com/en/.
}

Europe (e.g. the movement against Notre-Dames-Des-Landes airport, the NOTAV movement against the Lyon-Turin high-speed train project, etc.) and has met every year since 2010. In 2013, this movement organized a meeting during the World Social Forum in Tunis that resulted in the publication of the Tunis Charter. According to the collective "Des plumes dans le goudron", the innovation of this resistance movement against "unnecessary and imposed mega-projects" since 2010 has been to bring together different struggles against different types of infrastructures (e.g. airport, high-speed train, nuclear landfill, etc.) across different territories in Europe under the same banner and with the same analysis of the situation (see also Robert, 2014). To a certain extent, in the Global South, we can also witness some structuration of the movement at the national or regional level (see for instance McDonald, 2004 for South Africa; Porto, 2012 for Brazil; Williams and Mawdsley, 2006 for India).

However, the "alternative" and the "resistance" movements are not political movements in the traditional sense of the term, as they consist of disparate initiatives that are not politically united and may never be. In line with Pleyers (2010), we argue that the unity of these movements relies on social meanings shared by the actors and on the major challenges they face rather than sharing a single organizational structure or program. In this sense, the unity of these movements is not incompatible with a certain degree of heterogeneity among their actors. To some extent, one could say that resistance and alternative movements are locally rooted and transnationally connected.

Engagement in activism helps shape individual and collective identities (Curnow et al., 2018). For people participating in alternative movements we have witnessed the appearance of terms derived from the names of the movements to qualify the participants as "transitioners", "commoners", "degrowthers", etc. One could suggest that participation in this kind of movement helps shape the participant's identity through their belonging to these communities. For the environmental justice side, according to Anguelovski and Martinez-Alier, 2014 activists identify with the following claims: Equitable access to environmental goods and services; Right to livelihoods, to local cultural values, to place, and to territory; Contestation of capitalist production; and Valuation of place and protest against land appropriation and speculation (Anguelovski and Martinez-Alier (2014); for a more detailed analysis see Martinez-Alier et al., 2016). At the local level, Sebastien (2017) highlights the fact that engaging in local environmental resistance contributes to the development of what she calls patrimonial capital (place-attachment). This capital corresponds to the set of ties that activists establish with the local environment to be defended, which greatly promotes the emergence of shared collective identities. At the European level, as mentioned above, activists fighting against infrastructure projects recognize themselves or their local movement under the banner of resistance against "unnecessary and imposed" mega projects. In France, the illegal occupation (ZAD: Zone to defend) of the threatened land of Notre-Dames-Des-Landes has given birth to a particular identity of political activist: the "ZADiste."

In some cases, we can observe an interpenetration of networks and identities because some actors participate in both kinds of movements. The Alternatiba movement, ${ }^{6}$ which mainly organizes temporary "villages of alternatives" for two to three days in cities in France, Europe and soon in Africa, is a vivid example of this interpenetration. Indeed, the actors at the origin of the movement are also involved in multiple place-based struggles in the Basque region, especially against highspeed trains and mining projects. They also helped organize the most recent forum against unnecessary and imposed mega-projects in Bayonne in 2016. Two French authors (Kempf, 2014; Subra, 2016) who have studied the ZAD movement in France explain that, for the alterglobalization movement, it was time to be involved in local, concrete struggles. Geofrey Pleyers has also identified, at least for one important

${ }^{6}$ https://alternatiba.eu/. 
part of the alterglobalization movement, a shift toward the local after the 2008 financial crisis in order to obtain concrete outcomes by challenging the dominant ideology at the local level, in his major book on alterglobalization (2010). Thus, resistance and alternative movements interpenetrate each other.

Last but not least, both types of movements entail a specific type of collective action that is locally grounded. In line with Pleyers (2010), we can understand the importance accorded to places as a way to territorialize alterglobalization (more or less consciously). Pleyers (2010, p12) explains: "rather than seeking to change the agendas of policy makers, these activists want to implement their values and alternatives in their experience of daily life, in local communities and in the networks and organizations of the movement. They claim to create autonomous spaces...where they experiment with horizontal networks, alternative consumption and participatory processes". This is clearly a bottom-up concept of social change (ibid.). This bottom-up concept of social change is enacted through the implementation of "autonomous" spaces of "counterpower" where self-organization and self-determination can be experimented and strengthened. With varying degrees of autonomy and "political consciousness,"7 both alternative and resistance groups help create such spaces. As Gibson-Graham (2008) argued, these spaces are crucial for social change because they enable the possibility of other ways of being in the world. This makes it possible to challenge the dominant definition of time, space and value. Yet in a visionary paper in 2008, Gibson-Graham $(2008$, p659, 662) spoke of a revolutionary "politics of place" emerging all around the world: "While traditional revolutionary politics confronts a single space of dominion, the politics of place imagines and creates multiple spaces of freedom and self-determination. It is a politics of the here and now, embedded in place yet globally transformative." Therefore, there is a need for deeper reflection about the role of "places" as "spaces" in which socio-political transformations can occur. Indeed, there is a growing body of literature in geography and sociology (Featherstone and Korf, 2012; Nicholls et al., 2013; Combes et al., 2016; Dechézelles and Olive, 2016) that highlights the importance of "place," not just as a "context" or a "setting," but as a key element in the formation of collective action, social movements, and politicization processes.

Conclusively, both alternative and resistance movements seem to share some features. For instance, they offer people new forms of engagement, beyond consumerism and representative democracy, as well as networks to share experiences and knowledge. They create places where individual and collective empowerment can happen and where alternative lifestyles, identities, practices and values can be developed.

\section{Resistance and Alternative Movements: Difference or Continuity? Are They the Two Faces of the Same Coin?}

\subsection{Conflictual Versus Consensual Collective Action}

Although resistance and alternative movements have some features in common, it is also necessary to point out their differences. Della Porta and Diani (2006) differentiate between a social movement and a consensual movement. They explain that social movements adopt a conflictual character regarding the identification of political opponents in order to change the relation of power and power structures, while consensual movements do not. According to Della Porta and Diani (2006, p 23): "In both social movement and consensus movement dynamics, actors share solidarity and an interpretation of the world, enabling them to link specific acts and events in a longer time perspective. However, in the latter, sustained collective action does not take a conflictual element.

\footnotetext{
${ }^{7}$ There is considerable "political" latitude between alternative and resistance movements ranging from transition initiatives, for example, from the Catalan integral cooperative or the zone to be defended (ZAD) in Notre-Dames-desLandes in France to community supported agriculture and urban gardening.
}

Collective goods are often produced through cooperative efforts that neither imply nor require the identification of specific adversaries, trying to reduce the assets and opportunities of one's group or preventing chances to expand them. Prospected solutions do not imply redistribution of power nor alterations in social structure, but focus instead on service delivery, self-help, personal and community empowerment. Likewise, the practice and promotion of alternative lifestyles does not require the presence of opponents defined in social and political terms." Environmental resistance movements adopt the conflictual action standpoint through the development of oppositional practices and discourses. By confronting power overtly they also expose themselves to repression. Several scholars have noted the increase in criminalization and repression of environmental resistance movements, notably in Latin America, but also in Europe (Birss, 2017; Alonso Cidad et al., 2012; Des plumes dans le goudron, 2018; Le Billon, 2015; Mireanu, 2014). The Tunis charter emphasizes "the militarization and criminalization of opposition". This document makes reference to the massive presence of military forces and excessively armed riot police during demonstrations and to their intervention in the different land occupations. Moreover, in local environmental resistance movements, the promoter of the project (often the State and/or a global private company) sets the agenda. Consequently, the protestors are always reacting and they are always short on time. In contrast, one could argue that people involved in creating or developing alternatives usually master the agenda: they can take time to get to know each other to build trust, they can elaborate and work on the midto long-term plans (uncertainty can be handled to some extent), and if their initiative fails, no land, landscape, biodiversity or human lives are directly at stake.

However, resistance movements can give birth to alternative movements, and alternative movements can be seen as resistance movements. In fact, even though an oppositional action is at the origin of environmental resistance, this can give birth to alternative practices, when associated with land occupation for example. In this kind of case, resistance movements offer a space where alternative ways of living can be experimented with. For example, in the ZAD of Notre-Dames-DesLandes, or in the occupied valley of Val Di Susa (NoTav movement) in Italy, activists have implemented alternative practices such as agroecology, non-monetary exchanges of products, ecological housing, repair workshops, radio and local media, etc. Regarding alternative movements, actors involved in them do not engage in openly declared conflicts. Though, according to Chin and Mittelman (2000, p36), even if participants in alternative groups do not engage in open confrontation with the state or transnational corporations, "resistance has to be read as the ways in which peoples live their everyday life." According to the authors, counter-hegemonic consciousness can be involved in everyday practices and encounters with the community. But do alternative practices of consumption and production qualify as "everyday resistance" first forged by Scott (1985) to shed light on the hidden subversive discourses and practices that the subaltern actors implement when open confrontation is too risky or simply not possible? Vinthagen and Johansson (2013, p3) reminds us that "resistance" is an oppositional act and hence it is rather a practice than a consciousness, but they also emphasize the need to think in terms of continuity between public confrontation and hidden subversion: "everyday resistance suggests that resistance is integrated into social life and is a part of normality; not as dramatic or strange as assumed - even if it is still unclear how common it is". Temper et al. (2018) argue similarly and advocate that alternative movements can be both the root and the result of resistances processes. They explain that resistance and alternative movements are linked processes, people moving across the line: "protesting when they need, engaging in rebuilding when they need to" (Temper et al., 2018, p8).

This assertion follows the same direction as the ideas of John Holloway (2010, p6, p22) in his major book: Crack Capitalism. He argues that we should seek continuity between different forms of engagement rather than opposing them: 
"[...] It may seem strange to place the car worker who goes to his allotment in the evening next to the young man who goes to the jungle to devote his life to organising armed struggle against capitalism (he refers to subcommandate Marcos of the Zapatista movement). And yet there is a continuity. What both have in common is that they share in a movement of refusal-and-other-creation: they are rebels, not victims; subjects, not objects. In the case of the car worker, it is individual and just evenings and weekends; in the case of the young man in the jungle, it is a very perilous commitment to a life of rebellion. Very different and yet with a line of affinity that it would be very wrong to overlook. (p6) [...]. The car worker is watering his plants on the allotment today, but he may be out on the streets fighting Monsanto tomorrow (p22)".

In line with john Holloway, we advocate for continuity between these movements, but we also want to specify some points that should be investigated when looking at resistance and alternative movements using a social movement approach. These points constitute avenues for future research.

\subsection{Avenues for Future Research}

In this last sub-section we suggest four aspects that should be investigated further regarding the contribution of both alternative and resistance movements to transformations toward sustainability from a social movement perspective. These four aspects are: (i) to reflect on the radical or reformist aspect of the movement under study; (ii) to pay attention to which kind of conception of democracy the movement under study relies on i.e. deliberative democracy or radical democracy; (iii) to investigate how the movement positions itself regarding power relations and power structures and; (iv) to pay attention to the individual and collective politicization processes that occur during the course of the movement under study.

Regarding the first point, Temper et al. (2018) emphasize the need to differentiate between radical and reformist initiatives. They explain (p5) that "the word "Radicalis" comes from the Latin "of or having root" and refers to "change at the root" with connotations to fundamental and revolutionary change of social systems". They further explain that radical movements are those that are "confronting the basic structural reasons for unsustainability, inequity and injustice, such as capitalism, patriarchy, state centrism, or other inequities in power resulting from caste, ethnic, racial, and other social characteristics". On the contrary, they consider movements to be reformist if they only deal with the symptom of a problem. They do not offer clear criteria to draw the line between the two types of transformations, and perhaps it is not the point to do such a thing (see discussion above). However, we argue that it is worth asking ourselves (and the movement we observe or participate in), if the movement under study is trying to address (at least in the formulation of the problem) the roots or only touching the surface of the socio-ecological problem it is attempting to fix.

In relation to the second point, it is interesting to stress that, perhaps unconsciously, movements adopt two types of conception of democracy. On the one hand, movements can operate under the paradigm of deliberative democracy, seeking consensus and avoiding conflict (Habermasian perspective) by not challenging radically existing political institutions. On the other hand, movements can operate in the realm of radical democracy, in the sense of Mouffe (2005) and Rancière (1999), expressing conflict rather than avoiding it - even within the movement, by recognizing the diversity of political subjectivities that constitute it. The first type of movement participates in the creation/ renovation of the "public sphere" and the second creates what Oskar Negt (2007) has called "oppositional public spaces". It would be interesting to investigate further under which paradigm the different movements operate and to study if some movements switch from one paradigm to another through time.

Considering the third point, in line with Kenis (2016), we argue that the focus of research should be how the created "collectivity/ community" is able to view and position itself within a wider social, economic and political context of power relations. Studies should also examine the extent to which the movement acknowledges power and conflicting relations inside and outside the movement under consideration.

Fourthly, we would like to stress the need to investigate further the politicization processes that lead to the emergence of radical individual and collective subjectivities. Indeed, do alternative and resistance movements produce different politicized subjectivities and spaces? Who are the actors involved in both resistance and alternative movements and what is their role? How do they bridge the two movements? How do people switch from one to the other? How do alternative movements arise from resistance movements and vice versa? More fundamentally, how do these movements contribute to the task of repoliticizing nature and sustainability in general?

As a conclusion we formulate the following hypothesis: "Would a movement that creates alternative practices of production and consumption without placing itself (overtly or covertly) within a perspective of resistance against the actual hegemonic order remain reformist? Would a resistance movement that is not able to propose/create alternatives practices of production and consumption also remain reformist?" Only if both aspects are tackled by a movement will we observe radical transformations? From this perspective, resistance and alternative movements would actually be the two faces of the same coin i.e. social forces for transformation toward an emancipatory conception of sustainability.

\section{Concluding Perspectives}

In accordance with Scoones $(2016),{ }^{8}$ we argue that transformations to sustainability require a shift beyond scarcity discourses toward a politicized understanding of resources and sustainability. From this perspective we would like to stress the need for a truly "socio-political" approach to sustainability transformation processes in order to unravel the power relations that inevitably confront alternative and resistance movements are (both internally and externally). Indeed, sustainability issues are often depoliticized (Swyngedouw, 2014; Kenis and Lievens, 2014) and we believe a social movement perspective would better address this situation. According to Swyngedouw (2014, p90): "The Political is the contested public terrain where different imaginings of possible socio-ecological orders compete over the symbolic and material institutionalization of these visions... a terrain that makes visible and perceptible the heterogeneous views and desires that cut through the social body..." According to the same author, the re-emergence of the "Political" implies new practices of living together, the production of new egalitarian material, and discursive socio-ecological spatialities through the reappropriation of space (symbolic and material) and the production of new socio-ecological relations. In sum, it is about producing counterhegemonic, socio-ecological egalitarian discourses and practices. Therefore, if we re-frame the sustainability transformation debate in line with the above-mentioned concept of "the Political," the main research question would become: to what degree do these resistance and alternative movements challenge the socio-ecological dominant order? Or to be more specific, to what degree do they contribute to the reappropriation of material and symbolic space in order to produce new (conter-hegemonic) egalitarian socio-ecological relations across scales?

\section{Acknowledgement}

Jérôme Pelenc has beneficiated from a FNRS post-doctoral grant. He also thanks the team of the Acknowl-EJ (Academic-Activist CoProduced Knowledge for Environmental Justice) project (http:// acknowlej.org/). Many thanks to Rowland Hill for editing the

\footnotetext{
${ }^{8}$ Cited by Temper et al. (2018).
} 


\section{manuscript.}

\section{References}

Acosta, A., Martinez, E. (Eds.), 2009. El buen vivir. Una via para el desarrollo, Abya-Yala, Quito.

Acosta, A., Martinez, E. (Eds.), 2009. Derechos de la naturaleza. El futuro es ahora, AbyaYala, Quito.

Alonso Cidad, C., Barcena Hinojal, I., Gorostidi Bidaurrazaga, I., 2012. Repression and criminalization of the ecologist movement in the Basque Country: the case of the high speed train project. Oñati Socio-Leg. Ser. 4 (1), 13-34.

Anguelovski, I., Martinez-Alier, J., 2014. The 'environmentalism of the poor' revisited: territory and place in disconnected glocal struggles. Ecol. Econ. 102, 167-176.

Armiero, M., D'Alisa, G., 2012. Rights of resistance: the garbage struggles for environmental justice in Campania, Italy. Capital. Nat. Social. 23 (4), 52-68.

Avelino, F., Grin, J., Pel, B., Jhagroe, S., 2016. The politics of sustainability transitions. J. Environ. Policy Plan. 18 (5), 557-567.

Barbe, F., 2016. La «zone à défendre» de Notre-Dame-des-Landes ou l'habiter comme politique. Norois (238-239), 109-130.

Baumgärtner, S., Becker, C., Frank, K., Müller, B., Quaas, M., 2008. Relating the philosophy and practice of ecological economics: the role of concepts, models, and case studies in inter-and transdisciplinary sustainability research. Ecol. Econ. 67 (3), 384-393.

Beling, A.E., Vanhulst, J., Demaria, F., Rabi, V., Carballo, A.E., Pelenc, J., 2017. Discursive synergies for a 'great transformation' towards sustainability: pragmatic contributions to a necessary dialogue between human development, degrowth, and buen vivir. Ecological economics. Available online: http://www.sciencedirect.com/ science/article/pii/S0921800917303798.

Birss, M., 2017. Criminalizing environmental activism: as threats to the environment increase across Latin America, new laws and police practices take aim against the front line activists defending their land and resources. NACLA Rep. Am. 49 (3), 315-322.

Bollier, D., 2014. Think Like a Commoner. A Short Introduction to the Life of the Commons. New Society Publishers, Gabriola Island.

Castoriadis, C., 1975. L'institution imaginaire de la société. vol. 336 Seuil, Paris.

Castro e Silva, M., Teixeira, A.A., 2011. A bibliometric account of the evolution of EE in the last two decades: is ecological economics (becoming) a post-normal science? Ecol. Econ. 70 (5), 849-862.

Castoriadis, C., 1986. Domaine de l'homme les carrefours du labyrinthe II, Paris, Seuil, coll. Point essais.Domaine de l'homme les carrefours du labyrinthe II, Paris, Seuil, coll. Point essais.

Chin, C., Mittelman, J., 2000. Conceptualizing resistance to globalization. In: Gills, Barry (Ed.), Globalization and the Politics of Resistance. Palgrave, pp. 29-45.

Combes, H., Garibay, D., Goirand, C., 2016. Les lieux de la colère: occuper l'espace pour contester, de Madrid à Sanaa. Karthala. pp. 410.

Costanza, R., 1991. Ecological Economics: The Science and Management of Sustainability. Columbia University Press.

Curnow, J., Davis, A., Asher, L., 2018. Politicization in process: developing political concepts, practices, epistemologies, and identities through activist engagement. Am. Educ. Res. J. https://journals.sagepub.com/doi/abs/10.3102/0002831218804496.

Dechézelles, S., Olive, M., 2016. Conflits de lieux, lieux de conflits. Special issue, Revue Norois. pp. 238-239.

Della Porta, D., Diani, M., 2006. Social Movements: An Introduction. Blackwell.

Demaria, F., Schneider, F., Sekulova, F., Martinez-Alier, J., 2013. What is degrowth? From an activist slogan to a social movement. Environ. Values 22 (2), 191-215.

Demmer, U., Hummel, A., 2017. Degrowth, anthropology, and activist research: the ontological politics of science. J. Polit. Ecol. 24 (1), 610-622.

Des plumes dans le goudron, 2018. Résister aux grands projets inutiles et imposés - De Notre Dame des Landes à Bure, Paris, Editions textuel, Collection «Petite encyclopédie critique». (155 p).

Escobar, A., 2015. Degrowth, postdevelopment, and transitions: a preliminary conversation. Sustain. Sci. 10 (3), 451-462.

Featherstone, D., Korf, B., 2012. Introduction: space, contestation and the political. Geoforum 43 (4), 1-12.

Frère, B., 2010. La nouvelle économie sociale ou solidaire: une repolitisation du quotidien? Barricade. Liège.

Frère, B., Jacquemain, M., 2013. Résister au quotidien? Presses de Sciences Po.

Funtowicz, S.O., Ravetz, J.R., 1994. The worth of a songbird: ecological economics as a post-normal science. Ecol. Econ. 10 (3), 197-207.

Gendron, C., 2001. Émergence de nouveaux mouvements sociaux économiques. revue POUR. 172. pp. 175-181.

Gendron, C., Turcotte, M.-F., 2006. Mouvements sociaux économiques et gouvernance: une nouvelle structuration du marché?. Les cahiers de la Chaire - collection recherche No 14-2006.

Gibson-Graham, J.K., 2008. Remarx: "place-based globalism": a new imaginary of revolution. Rethink. Marx. 20 (4), 659-664.

Grisoni, A., 2015. Les mouvements d'opposition contre les Grands projets inutiles imposés (GPII) à l'avant-garde de la ruralité? Mouvements 4, 126-130.

Hart, K., Laville, J.-L., Cattani, D., 2010. The Human Economy. A Citizen's Guide. Polity Press, Cambridge (dir.).

Holloway, J., 2010. Crack Capitalism. Pluto Press, UK.

Hopkins, R., 2008. The Transition Handbook. From Oil Dependency to Local Resilience.

Hopkins, R., 2013. The Power of Just Doing Stuff: How Local Action Can Change the World. Transition Books, Croydon.

Jahn, T., Bergmann, M., Keil, F., 2012. Transdisciplinarity: between mainstreaming and marginalization. Ecol. Econ. 79, 1-10.

Kemp, et al., 2016. The humanization of the economy through social innovation. In: Paper Presented at the SPRU 50th Anniversary Conference. . http://kemp.unu-merit. $\mathrm{nl} /$ docs/The\%20humanization\%20of\%20the\%20economy\%20-\%20Kemp\%20et \%20al\%20for\%20SPRU\%20conference\%202016.pdf.

Kempf, H., 2014. Notre-Dame-des-Landes. Le Seuil.

Kenis, A., 2016. Ecological citizenship and democracy: Communitarian versus agonistic perspectives. Environ. Politics 25 (6), 949-970.

Kenis, A., Lievens, M., 2014. Searching for 'the political' in environmental politics. Environ. Polit. 23 (4), 531-548.

Laville, J.L., 2010. The solidarity economy: an international movement. In: RCCS Annual Review. A Selection From the Portuguese Journal Revista Crítica de Ciências Sociais. 2.

Le Billon, P., 2015. Environmental conflict. In: The Routledge Handbook of Political Ecology, pp. 598-608.

Martinez-Alier, J., Temper, L., Del Bene, D., Scheidel, A., 2016. Is there a global environmental justice movement? J. Peasant Stud. 1-25.

McDonald, D.A. (Ed.), 2004. Environmental Justice in South Africa. Juta and Company Ltd, London.

Mireanu, M., 2014. The criminalisation of environmental activism in Europe The lefteast, September 24. accessed online: http://www.criticatac.ro/lefteast/criminalisation-ofenvironmental-activism-in-europe/.

Mouffe, C., 2005. On the Political. Routledge, Abingdon - New York.

Negt, O., 2007. L'espace public oppositionnel. Payot.

Nicholls, W., Miller, B., Beaumont, J., 2013. Conceptualizing the spatialities of social movements. In: Spaces of Contention: Spatialities and Social Movements, pp. 1-23.

Pelling, M., 2011. Adaptation to Climate Change: From Resilience to Transformation. Routledge, Abingdon.

Pleyers, G., 2010. Alter-globalization: becoming actors in a global age. In: Polity.

Pleyers, G., 2011. La consommation critique. Paris, Desclée de Brouwer. (Dir.).

Porto, M.F., 2012. Movements and the network of environmental justice in Brazil. Environ. Justice 5 (2), 100-104.

Rancière, J., 1999. Disagreement: Politics and Philosophy. University of Minnesota Press, Minneapolis.

Robert, D., 2014. Social Movements Opposing Mega-Projects: A Rhizome of Resistance to Neoliberalism (Master thesis). KTH, Stockholm. http://stophs2.org/wpcontent/ uploads/2014/12/D-Robert-Social-movements-against-UIMP.compressed.pdf.

Scoones, I., 2016. The politics of sustainability and development. Annu. Rev. Environ. Resour. 41, 293-319.

Scott, James C., 1985. Weapons of the Weak: Everyday Forms of Peasant Resistance. Yale University Press.

Sebastien, L., 2017. From NIMBY to enlightened resistance: a framework proposal to decrypt land-use disputes based on a landfill opposition case in France. Local Environ. 22 (4), 461-477.

Sikor, T., Newell, P., 2014. Globalizing environmental justice. Geoforum 54, 151-157.

Stirling, A., 2015. Emancipating transformation: from controlling 'the transition' to culturing plural radical progress. In: Scoones, I., Leach, M., Newell, P. (Eds.), The Politics of Green Transformations. Routledge, Oxon, pp. 54-67.

Subra, P., 2016. Zone à defendre. Ed de l'Aube.

Swyngedouw, E., 2014. Depolitization (the political). In: D'Alisa, G., Demaria, F., Kallis, G. (Eds.), Degrowth: A Vocabulary for a New Era. Routledge, pp. 90-93.

Swyngedouw, E., Kaika, M., 2014. Urban political ecology. Great promises, deadlock... and new beginnings? Documents d'anàlisi geogràfica 60 (3), 459-481.

Temper, L., del Bene, D., Martinez-Alier, J., 2015. Mapping the frontiers and front lines of global environmental justice: the EJAtlas. J. Polit. Ecol. 22, 255-278.

Temper, L., Walter, M., Rodriguez, I., Kothari, A., Turhan, E., 2018. A perspective on radical transformations to sustainability: resistances, movements and alternatives. Sustain. Sci. 13 (3), 747-764.

Vinthagen, S., Johansson, A., 2013. 'Everyday resistance': exploration of a concept and its theories. Resist. Stud. Mag. 1 (1), 1-46.

Williams, G., Mawdsley, E., 2006. Postcolonial environmental justice: government and governance in India. Geoforum 37 (5), 660-670. 